\title{
Protest and Voice from Margin in Poetry: In Reference to the "Brown Africa" and Aafar
}

- Rudra Bahadur Charmakar*.

\begin{abstract}
:
The present article explores the expression of the protest and voices of the Dalits on the basis of poems written on the Dalit issues and subjects. It also examines how Dalits as subalterns speak for the causes against their discrimination, exploitation and socio-political exclusion. Poetry is an appropriate medium to express the feelings and socio-political reality of our society; so as protest poetry portrays the Dalit problems in general, and rigorously upholds the rights, equality, dignity and social liberation. The findings of the article show that the poetic features, messages and themes are expressed as the voices of the subalterns with pain, anger and revolt. The poetry raises the voice for justice and liberation; and also encourages the Dalits to move against the discrimination. The protest poetry questions the credibility and validity of the historiography of the Dalits and asks for compensation against centuries-long discrimination and exclusion. The article is developed based on the selected poems of Aahuti and Harisharan Pariyar by critically analyzing them from subaltern perspective.
\end{abstract}

Key words: Poetry, protest, liberation, subaltern, and historiography

\section{Introduction and Rationale:}

Oxford Advanced Learner's Dictionary (Sixth Edition, 2000) defines poem as "a piece of writing in which the words are chosen for their sound and the images they suggest, not just for their obvious meanings. The words are arranged in separate lines, usually with a repeated rhythm, and sometimes the lines RHYME at the end" (972). Poems have their own literary features, characteristics, rhythm, diction, meter and formula which the poets have to follow. Composing the poems is a difficult task because of its poetic rules and formula. However, poetry is a good medium to communicate to the readers and audiences and express the feelings regarding the issues in poetic and literary short form. It is one of the genres of literature. Regarding the poem, Aahuti in his article "Mero Kabitako Katha" (2071) opines, "...an expression of various dictions with certain rhythms by using the metaphors and symbols on realistic context where people put their feelings and opinions in

\footnotetext{
*Mr. Charmakar is a PhD scholar and assistant professor of English at Patan Multiple Campus, TU, Nepal.
} 
concise form; that is poem" (103). Human being is a creature which always thinks about symbols and webs the symbols of wishes. The romantic poets regard poetry as a product of imagination and nature. In "Preface" to Lyrical Ballards, William Wordsworth (1805) defines poetry as "the spontaneous overflow of powerful feelings: it takes its origin from emotion recollected in tranquility" (4). Unlike romantic poetry, realist and postmodern poetry expresses the socio-political reality and portrays the problems and loopholes of society; and brings the voices of protest in the space with certain purpose.

Nepali Dalit poets write the poems with a mission for socio-political transformation. They pick up the issues and problems of our social structures and surroundings; and try to find the solution which gives eternal satisfactions to them. The poetry written on Dalit issues and subjects brings the issues of socio-political discrimination, oppression, boycott, exclusion and marginalization on the basis of caste system; and they uphold concepts of rights, equality, dignity and social liberation. Poet PabitraSunarwrites that "The morning glory is already spread// It is already been morning// Why are you unknown about it? // The morning glory of Eastern region// Why do not you see? // The rays of Sun? // Because//Your eyes// are tied with bandage" (trans. "Byunjha Aba ShoshitHo [Wake up now all the Oppressed]" 2073 BS., 47). Here, Sunar appeals to the Dalits and oppressed communities who have been struggling for their rights, equality, dignity and social liberation. Regarding Dalit writers, Savyasaachi in his article "Dalit Studies: Exploring Criteria for a New Discipline" (2004) states, "prosperity of Dalit leads to identity searching still their voices are suppressed" (1658). They search for their identity and upliftment of voices; and their voices are for equality and Dalit liberation.

Most of Nepali poetry by Dalits and writers from marginalized communities is composed with socio-political mission for certain community issues and subjects. The recent trends of poetry are more focused on those very issues of the societies. Dalit poets pick the sociopolitical issues and problems up and raise the voice for the comprehensive solution. Poetry written on Dalit issues and subjects has particular aims in the society. In current situation, there are numerous poems written on socio-political subjects and issues of Dalits. However, Dalit poetry has not been critically studied from subaltern perspectiveto date. This article is mainly focused on how the poems written by Dalit poets are thematically composed? What are the purposes? How the voices are raised through poems? What are the subjects and issues in the poems? The research article attempts to bring the inherent issues of Nepali poetry writing which unveils the socio-political realities of its mission, objectives, themes and approaches on the poetry written on Dalits' issues and subjects mainly by the Dalit poets. Moreover, the article attempts to explore the need of prescribing the protest literature in higher education and academia of Nepal to end the all forms of social discrimination from 
the society. The researcher has purposefully employed the concept of Subaltern Studies as theoretical tool and has adopted qualitative approach.

\section{Literature Review:}

Poems are composed to share the inner or internal feelings of poets to readers or audiences. Most of the poems are composed with mainly two purposes-portraying the society and providing the entertainment. However, the most important purpose of poems written on Dalit issues and subject is for social justice and liberation. In the context of Nepal, some poets from marginalized communities and proactive non-Dalits compose the poems for rights, equality and liberation. It breaks the traditional concept of poetic styles. And, the poems composed on Dalit issues uphold for the Dalits' equality and dignified lives. Specially, the poems on Dalit issues express the pain, grief, and agony of Dalits which the community has been facing the numerous difficulties and discrimination for centuries based on their position and castes. They express the voice of anger and revolt to liberate them from the situation.

Writing poetry/poems for social liberation was begun from 1940s in Nepal. In the beginning days, Dalit poets published their poems in wallpapers and leaves. Padam Sundas writes about the account of writing poems by Dalits that "T.R. Bishwakarma started writing about Dalit literature with poem in 1950 AD. He had written poem on thewallpapers as a part of Dalit literature. His published literary writings were found: Banchne Thulo (2017), Maatora Mutu (2050), Yugin Sachetanaka Swarharu (2064)" (Sundas, 2070). These are collection of poems and other writings. The Bhakti poet of Nepal, Yogmaya Koirala (Bhojpur) had also composed poems for social equality and liberation in 1930s but her writings and poems were published recently as "Sawartha Yogbani in 2059 BS" (Chapagain, 2070, p. 60). Many non-Dalit poets such as the great Laxmi Prasad Devkota had advocated for Dalit liberation in his poems. Devkotadedicates a song toDamai Dai (socially so called Dalit) in 1954 AD that "The needle pinched the heart Damai Dai// by looking at the nation today// The insect ate leaf, Damai Dai// by looking at the panic of nation" (trans. "Damai Dai [Damai Brother]", qtd. in Chapagain, 207, p 61). It was the time of early democratic period and the nation was in problems the same as the Dalits; and Dalit community was unable to practice the freedom and liberty so far. Devkota uses the metaphors of needle, torn leaf and nation of the then time which seem terrible.

Devkota had composed many poems by dedicating to Dalit and marginalized people in his latter days as well. "Devkota's poems "Ek Sundari Chyaminiprati (Dedicated to A Beautiful Chyamini), 2013" and "Sarki, 2015" express directly and indirectly that liberation was not possible without struggles" (Chapagain, 2070, p. 63). The contemporary situation of the Dalits and other marginalized communities was terrible. According to the critic Ninu 
Chapagain, many poets and writers such as Kewalpure Kisan, Bhanu Bhakta Pokharel, Siddhicharan Shrestha, Bhimnidhi Tiwari, Paarijaat, Modnath Prashrit wrote poems and literary writings for the Dalits and marginalized communities. They tried to uphold Dalit liberation and freedom from their side through poetry/literature. (2070, pp. 63-66)

Poetry on Dalit issues and subjects aims to make the Dalit's and wider society conscious about the oppression and discrimination of Dalits based on caste system. Dalit poets appeal to the people to join their hands for liberation of Dalits. Dalits as subaltern try to make their conditions and consciousness public as Gayatri Chakravorty Spivak argues, "the subalterns are trying to uncover the (singular) "consciousness" of the (plural) subaltern, thereby looking for and ultimately establishing through...positivist subaltern consciousness" (qtd. in Brueck, 2014, p. 67). Dalit poets reflect the consciousness in their poems. As Pabitra Sunar states, "Not darkness// but we should bring the happiness// Not prohibition// but we should get the liberation// Oh ruled! Wake up// but we should see the rays of light// Wake up, Oh Dalit! // We should get the path of liberation. (trans. "Byunjha Aba Shoshit Ho [Wake up Now, the Oppressed] "Sunar, 2073, p. 48). Sunar, here, appeals to Dalits to move ahead for happiness, liberation and freedom.

Dalit writers/poets speak for the Dalits' liberation in their writings. They are conscious about the reasons and results of the discrimination, and so they speak. The consciousness positively alienates Dalits and people from the discriminatory society. To quote Ranjit Guha (1982), "the task of the 'consciousness' of class or collectivity within a social field of exploitation and domination is thus necessarily self-alienating..." (342). Dalit writers speak against the exploitation and domination of Dalit community; and isolate themselves from the other communities. The radical poets/writers generate their own radical stream (the stream isolated from classical writing stream; and they want liberation) in Nepal as Unmutka Pusta refereed as "liberated generation" (trans. Nepali Brihat Shabdakosh, 2067, p. 140). The radical stream believes, "Unmukta Pusta [liberated generation] ... is a group of independent writers who are proactively writing against social, political, economic and cultural discrimination. The group is also free from casteism, religious, regional, gender, linguistics and political orthodox concepts" (trans. "Yeskaran Unmukta Pusta Aandolan [So that Liberated Movement" 2073, p. 97). The stream dreams for eternal freedom, happiness and fraternity. It believes that to be free from various barriers is dream of people; it is a grand responsibility of human beings as well.

The liberated generation questions the discriminatory systems, structures and social malpractices. One member of unmuktapusta, Kewal Banabee raised the questions, "Ultimately why// should shudra not study the Vedas? // Ultimately why// should shudra not listen to the Vedas? // Ultimately why// should shudra not have life? (trans. "Shoodra 
Shambuk", 2073, p. 12). The orthodox interpreters prohibited the shoodras from the access of reading the Holy Scriptures; so as the poet questions to the concept of prohibition. The poet raises serious issues through the poem "As described in the Vedas// the fake is okay// For instant, your forefathers// were born from mouths// My forefathers// were born from feet// But, what a paradox! // Your mother and my mother's// same organs from where we were born// Ultimately why// Like you, I am untouchable// and like me, you are touchable? (trans. Binabee, 2073, pp. 12- 13). The stanza seriously expresses her dissatisfaction on the discriminatory interpretation of Holy Scriptures. Really, were shoodras born from the feet? Is it possible? As we know the particular organs are there for giving the birth to mammals. Who believes the shoodras were born from feet? The poet raises a very important question regarding the birth process of shoodras. In this connection, Saraha Beth Hunt writes about Shambuk in her book Hindi Dalit Literature and the Politics of Representation that "In Dalit narratives, the character of Shambuk, who speaks out against the injustice of Ramrajya, serves to further highlight the importance of individual political assertion in the creation of a just society" (Hunt, 2014, p. 97). It was regarded a big crime if one would speak against the injustice as Shambuk did in Ramrajya. Hence, Sudra and other varnas are the same physically and mentally but how can one be untouchable and another be touchable?

These types of poems are exemplary of protest literature. Dalit literature is a part of protest literature. However, Padam Sundas is not satisfied with it because "Dalit literary movement is not considered as part of Dalit liberation movement which is the main problem of not raising the Dalit literature as expected" (Sundas, 2070, p. 47). The leaders of Dalit movements and poets/writers from Dalit community do not consider that they are complementary to each other. Similarly, there is not a strong guiding organization of Dalit writers; and the National Academy also hardly represents the Dalits in its structure.

Dalit protest literature is developed or written for the rights, equality, dignity and social liberation of Dalits of our society. Ranjana Nagar in her article "Defining Dalit Aesthetics" writes that "Dalit literature is concerned with the pains and sufferings of these people and their revolts and struggles to carve a place for them. Its intension is to make readers restless and angry" (Nagar, 2017, p. 127). Dalit literature expresses the voices of Dalits and marginalized people. And, thepoetry also does the same. It is an inseparable part of Dalit literature. However, literature is not considered as the part of movement by Dalit movement. Similarly, the issues and voices expressed through poems/poetry are not critically analyzed and spread in the wider society. In this very context, the research article attempts to critically study the poetry written on Dalit issues and subjects from subaltern perspective and fulfill the gaps and lacks of academic research on Dalits as subalterns. It also attempts 
to explore the need of protest literature in the higher education and academia to end all types of social discrimination.

\section{Methodology and Methods}

The account of Dalit literary writings shows that there was no specific measuring parameter of impacts, themes and features of Dalit literature including poetry. The present research article aims to explore the casteism, consciousness and voice of protest in poetic writing on Dalit issues and subjects. For this purpose, the researcher hastaken the references from Aahuti's Brown Africa and Hari Sharan Pariyar's selected poems from Aafar, an anthology of poems as primary texts. The researcher has applied the concept of Subaltern Studies as theoretical tool to critically study the selected poems.

The Subaltern Studies as a theory was formally developed in 1980s in India in the initiation of Ranjit Guha and his study group. However, the Subaltern as a concurrent discourse has been used to characterize the colonial subject by the European with subordinate identity of the Subaltern that has been constructed by the European discourse and internalized by colonial peoples. The term subaltern refers to those people who are deprived of the opportunities and access to every aspect of the nation. The elite people only valorize their own cultures, religion, castes, at the expense of the culture, religion, beliefs, and castes of the marginalized. The issues of the marginalized have always been neglected or forgotten. Since their voices are not included in the mainstream history, historiography and literature, the subaltern writers tried to identify subalternityas an autonomous genre in the late twentieth century. Regarding the historiography and subalternity, Italian Marxist, Antonio Gramsci argues that "the history of the subaltern is necessarily fragmented and episodic..." (qtd. in Guha, 1982, pp. 357-358). The subalterns' history is not found chronological and cohesive due to the state or elite's negligence to include the issues, voices and incidents in their made historiography.

Originally, the term 'Subaltern' would denote the inferior rank in military suggesting peasant origin. The historians and writers commenced writing about military campaign from the subaltern point of view in the nineteenth century. Ranjit Guha (1982) defines:

The word 'subaltern' in the title stands for the meaning as given in the Concise Oxford Dictionary, that is, 'of inferior rank'. It will be used in these pages as a name for the general attributes of subordination in South Asian society whether this is expressed in terms of class, caste, age, gender and office or any other way. (Subaltern Studies I, p. vii)

Ranjit Guha gives a clear account of Subaltern history and genealogy in Subaltern Studies I and other succeeding volumes of Subaltern studies. 
The scope of the subalternity has broadened since 1982 onward and they started to entail all who are deprived of basic rights and privileges under this concept. The histories, politics, economics, sociology, culture of the subaltern have appeared explicitly and directly which paved the way for the awareness of those marginalized people. They aimed at examining the general attribute of subordination of South Asian people in terms of class, caste, age, gender etc. The elitist historiography did not incorporate and acknowledge the contribution made by subaltern in the betterment of the nation. The elite history does not give the space to subaltern people; as Guha argues referring to the concept of Gardner, "history was written by the elite, for the elite and about the elite and this type of one-sided view leaves a gap in history" (Guha, 1982, p. 64). He sees the need of rewriting the history from the margin or subaltern perspective.

In course of time, Subaltern Studies emerged as a genre of change in the changed politicoacademic scenario, especially, because of the influence of post modernism and post structuralism. On the other hand, cultural studies were getting proximate to other disciplines and studies. In this backdrop, Subaltern Studies started to include the writing of the cultural theorists like Gayatri Chakravorty Spivak and Bernard S. Cohn, who brought cultural perspective in Subaltern Studies. In Spivak's article "Subaltern Studies: Deconstructing Historiography" (Subaltern Studies IV 1986), Spivak gave a linguistic as well as cultural mode to subaltern studies. She states, "the possibility of action lies in the dynamics of the disruption of this object, the breaking and relinking of the chain. This line of argument does not set consciousness against the social, but sees it as if self also constituted as and on a semiotic chain" (Spivak, 1986, p. 332). The subaltern studies in its later phase, broke the existing concept and restructured itself as an interdisciplinary discourse by relinking different disciplines in a chain. Later on, the writers like Susie Tharu and Amitav Ghosh followed her strengthening the feminist issues raised by her. Subaltern Studies was, then, changing rapidly with unprecedented momentum, however, socialist, communist and Marxist systems were deteriorating throughout the world and the academic world was moving towards Post-Marxist Studies. In such a context, subaltern studies remained the only domain which could provide a platform to the third world voices, so it remained as the beacon of hope for the marginalized.

In subaltern literature, the writers bring the issues, subject matters and concept of marginalized people. They also think from margins and they give the space to those who are excluded from elite and mainstream literature. Expressing the pain, agony, tension, exploitation, discrimination, oppression and suppression and at the same time issues of revolt, protest movements, radical change, equality, rights, dignity and social liberation are the key features, beauty or aesthetics of subaltern writings and literature. The subaltern 
studies opposes all the national- colonial histories. Subaltern Studies is a democratic project to generate the peasants as citizens in contemporary political modernity. In this article the researcher will critically analyze the Nepali Dalit protest poetry borrowing the concepts from RanjitGuha, GayatriChakravortySpivakand so on.

\section{Protest and Voices from the Margin againstCasteism in Nepali Poems}

The poets in Dalit literature express the pains, sufferings, problems, social differences and at the same time aware the society. The South Indian Marathi Dalit Popular writer and critic Sharan Kumar Limbale (2004) remarks that "the form of Dalit literature is inherent in its Dalitness and its purpose is obvious: to inform Dalit society of its slavery, and narrates its pain and suffering to upper caste Hindus" (Limbale, 2004, p. 19). Dalit literature portrays not only the social reality and problems of Dalits but also advocates for equality and rights with social revolt and protest. "Dalit Literature deconstructs and questions the very foundation... and construct the new story" (Nagar, 2017, p. 129). Bringing the realistic lives of Dalits in literature is immense beauty and aesthetics of Dalit literature.

Nepali Dalit writers always pick up the social-political problems and discrimination and appeal for revolt as well in their literary creation. "The new generation of Dalit poetry appeared in the contemporary period as a protest or rebellion against the oppressive traditional shackles" (Bala, 2014, p. 40). Poetry is taken a strong advocacy tool of protest for the contemporary poets. People speak against the system when they feel the discrimination. Vanay Bahl referring to Dipesh Chakrabarty in his article "Relevance (or irrelevance) of Subaltern Studies" argues that "process of change in the society...the tendency in Marxist construction of working class history within which the question of 'consciousness' is placed" (qtd. in Bahl, 1997, p. 1336). A subaltern character questions the society and historiography as soon as he is completely conscious about 'the oppressive traditional shackles'. The popular writers, critic, poet and politician Aahuti (2014) writes his poem "Brown Africa" as: My red blood

Pure red blood of a human

When it spills

As a drop of blue sweat

You collect it

In the furrows of your soft cupped palms

When I try to snort away that sweat

Redolent with labor

You humiliate and distance me

Have the nerve to meet my eyes, priest!

I am the twentieth century's "untouchable"!

The brown Africa of this round rock!

I claim justice 
I claim freedom! ("First Stanza"Aahuti, 2014, p. 9)

Aahuti bitterly expresses social reality of Dalits that the blood and sweat poured by Dalits are pure; the labor and effort are acceptable; the works are acceptable but their physical presence in socio-cultural programs is impure and unacceptable. The so-called upper caste people dishonor their presence and keep them away from socio-cultural programs. The priests do not allow them cross the thresholds of temples. Dalits are still treated as untouchables in twenty-first century. And, Aahuti further wishes for social justice and eternal liberation.

Dalits contribute to the society in everyday life. They support to the elites of the society for the elites' purposes. The subalterns are used to get steps up by elites of the society. In this connection Ranjit Guha (1982) argues that "...the subalternity common to all the social constituents...distinguished it sharply from that of elite politics" (Subaltern Studies I 05). The subalterns are made to fulfill the social needs of the elites. So, Aahuti raises the questions about the contribution of Dalits in social activities. He further interrogates why the labor and sweats of a Dalit is utilized but their existence is not accepted: "The smell of my forge is in your temple idol// The smell of my sweat in the pan// on your hearth' tripod// have the nerve of meet my eyes, pious one" ("Stanza II"Aahuti, 2014, p. 9). He is not happy with the treatment given by the society to the Dalits in particular and the oppressed in general because the society humiliates a Dalit in every sphere of life because he is socially considered lower caste as African (black). The Kami, who makes the idol of temple, but is not allowed to touch as soon as the idol is placed in the temple. Aahuti expresses his dissatisfaction and anger because of the very discrimination by the society.

Aahuti questions why Chyame, who cleans our surroundings and keeps the environment hygienic is untouchable for the society. The same blood flows in our veins and body, however, why is Dalit untouchable? He severely throws the questions to the upper caste society "Sniff the clean floor of your dwelling//The smell of my blood// is in the very flesh of your abode// Have the nerve to meet my eyes, clean one! //..." ("Stanza II" Aahuti, 2014, p. 10). These are the serious questions that the upper caste society has to answer. The people who give the full entertainments through music and tune as Gaine and Badi, are still prohibited to attend the public functions directly. This is really a grave crime against humanity.

The society must accept the existence of all people as equal. Dalits as Kami, Damai, Sarki, Gaine, Badi, Chyame or Musahar, all are humans and they have been supporting to the society so that the society is systematically running in its pace. If there were not this community; the society would have to face many problems due to the lack of social roles and responsibilities. But the society does not understand the social reality and contribution 
of the Dalits. Hence, Aahuti wants to take revenge and true payback from the Varna-based Hindu society. He wants the justice and proper compensation to the community that has been giving effort, labor and works for centuries. He further aggressively writes:

From the shoe on your foot

to the cap on your head

From the farthest horizon of your vision

to the rhythm of your heart

Am I nowhere? I am everywhere!

How can you make me "untouchable", touchable one?

Either have the nerve to stand in history's witness box

Or have the courage to change yourself

Have the nerve to meet my eyes priest!

I am the twentieth century's "untouchable"!

The brown Africa of this round rock!

I claim the accounting of humiliated history

At any cost I claim freedom! (Aahuti, 2014, pp. 10-11)

Dalit community is skillful; and provides services to society from foot to head, from garden to home, from birth rites to death rites. Their presence is needed everywhere; however, they are rejected everywhere. Why are they treated as untouchable? The history shows the real contributions made by the Dalits during the nation building process to every democratic movement. Nobody can delete the history but still why Dalit contributions are excluded or disregarded in the pages of history! The poet asks for exact accounting and extra compensation or payback of the entire efforts and contributions of Dalits and that is for equality, justice and freedom from all socio-economic, political and cultural barriers. Aahuti's poem "Brown Africa" has brought the waves in the Dalit social movements of Nepal and the orthodox Varna-based society could not respond or address to the Dalit issues logically and meaningfully.

Dalit writers and poets like Aahuti not only bring the realistic problems of Dalits but also appeal to the society to fight against all types of evil practices; and to change the system. It is considered that only Dalit literature can bring the issues of Dalit community properly. In this context, Sharan Kumar Limbale argues "only Dalit writers have narrated the pain of Dalits- this is true as the fact that rural writers have not depicted the life of Dalits... and Dalits have voiced their dissatisfaction against the unequal Hindu caste system" (Limbale, 2004, p. 29). The dissatisfaction is expressed through various forms and genres of literature.

Similarly, the Unmukta Pustaa [Liberated Generation]'s Aafar, an anthology of poems, is the outcomes of consciousness as voices of protest for rights and equality of Dalits. The 
writers of Unmukta Pustaa are politically aware; so that, they write for Dalits and marginalized communities. They began to write in unified form against discrimination through Aafar. The Aafaris the continuation of unique social movements of these writers. They declare "the poems included in the Aafar are not only free from the traditional writing styles and symbols but also they severely attack to them" (trans. Aafar, 2073, p. 7). The individual writing does not matter in the society so as the Unmukta Pustaa's effort is Aafar with clear social perception of this group.

The social hierarchy of Hindu Varna system is connected to the caste hierarchy in South Asia. The hierarchy has created a huge gap, and has drawn a boundary between the Dalits and non-Dalits. The Dalit literature also reflects the caste and Varna system. Furthermore, it not only reflects the ground reality of Dalits but also producesthe consciousness and speaks for rights, equality, identity, dignity and liberation. Dalits as subalterns are sidelined in socio-political system of Nepal. The traditional historiography has not included the issues of subaltern because the elite politics is always in vertical mode. According to Ranjit Guha (1982), "Mobilization in the domain of elite politics was achieved vertically whereas in that of subaltern politics this was achieved horizontally" (Subaltern Studies I, p. 04). The subaltern politics cannot move vertically; it should move horizontally at the mode of achievement. The elite politics get legal and constitutional support with their orientation whereas subaltern has to take the help of violence. The writers/poets' creations/compositions also express the voices of protest and violence, if needed, in their writings; and motivate the readers and audiences to act for socio-political rights and equality. Dalit poets like Harisharan Pariyar writes poems with the mission of blurring the socio-political discrimination and exploitation that Dalit community has been facing from centuries. His poem "Sanai (refereed to Pipe)" is an example of protest poem. Pariyar asks for identity of Damai caste with social respect in the poem as "Yes, I am Damai// Sanai (The Pipe) -// is my identity// is my pride// is my glorious work// is my history" (trans. "Stanza VI", 2073, p. 86). As a protest, the poetic persona is happy with his caste that it is his identity, glory and history but he wants social respect. He celebrates it with glorious history; however, his duty is still there to wake up the people for social liberation.

Dalits need to have a true identity of their own for their cause and rights. Gayatri Chakravorty Spivak in her article "Can Subaltern Speak? (1988)" argues that "For the 'true' subaltern group, whose identity is its difference, there is no un-representable subaltern subject that can know and speak itself; the intellectual's solution is not to abstain from representation" (Spivak, 1988, p. 27) The Subaltern group wants their identity with representation; they cannot speak with their vocal-curd but they speak with/through their writings which make the people conscious. The writings encourage the people to blur the 
boundaries of caste and class. HarisharanPariyar writes in the last stanza of his poem that "It needs to play the pipe// with thirty-six tunes// with thirty-six melody// and wake up// to the oppressed settlements//" (trans. "Stanza VIII", 2073, p. 86). The different tunes of the playing pipe not only give the melody and entertaining tunes but also wake the people up and raise the voices for ending all types of discriminatory social practices. The poetic persona believes that the effort of playing pipe has power to unite the Dalits to protest against all the malpractices imposed on them.

Dalit writers/poets raise the questions regarding the true accounts and the historiography of their contributions. Their forefathers and ancestors made tremendous contributions in the nation building process through different ways. But the elite history hardly recorded their contribution in the historiography. And, the conscious subaltern leaders and writers have asked for compensation of those contributions and sacrifices. Regarding the question of accounts of the contributions in historiography, Ranajit Guha argues:

Taken as a whole and in the abstract this...category...was heterogeneous in its composition and thanks to the uneven character of regional economic and social development, different from area to area. The same class or element which was dominant in one area...could be among the dominated in another. This could and did create many ambiguities and contradictions in attitudes and alliances, especially among the lowest strata of the rural gentry, impoverished landlords, rich peasants and upper middle class peasants all of whom belonged, ideally speaking, to the category of people or subaltern classes. (qtd. in Spivak, 1988, p. 26)

Guha believes that Subaltern can speak ideally for their rights. Here, Harisharan Pariyar's poem "Pasinako Hisab [The Compensation of Sweats]" speaks through poetic persona that "But, father// wearing the daura-suruwal (National dress of Nepal) made with our efforts// scattering our caste dignity// seizing our efforts// the modern feudal// irrigating glory from centuries// own land of our feet//" (trans. "Stanza III", 2073, p. 87). The elitesand feudals of our society are enjoying with Dalits' efforts, works and products but Dalits have no dignity, respect and even clothes for them. They are living for other. They are working for the society but they cannot get the wages, compensation and true acknowledgement; rather they get discrimination, boycott and exploitation in return. This is the destiny of Dalits in the society.

Dalit poets awake the society and the people for rights and equality of their castes and communities. They raise the voices of marginal people with mission and purpose of bringing back equality and liberation from the discriminatory practices of Varna system. Hence, Pariyar's next stanza expresses his anger and revolt against the Varna system. He further writes: 
So that,

Father...

Wake up now

From the rectangle cremation of aaryaghat (Cremation place of Hindus in Kathmandu)

And...,

Give me

Irrigated with sweats from years

Melting your skeleton

In the workshop of new era

To make a new weapon

To make the prison of feudal

And...,

Asking with one mana grain

Not to pay

The compensation of the sweats our forefathers. (trans. "Pasinako Hisab" "Stanza IV", 2073, p. 88)

The poet expresses the anger and also appeals Dalits to raise the voices against the centuries long discriminatory systems and practices. The poet, as a member of liberated literary movement (unmukta sahityik aandolan) wishes to have overall liberation of Dalit community in the society. He advocates for social dignity and social liberation breaking all the barriers of caste, culture, religion and social atrocities.

Dalit writers/poets portray the social realities in their writings. Harisharan Pariyar's poem "Kainchi (The Scissors)" also depicts the true pictures of Dalit occupational castes and speaks the voice of consciousness of Dalits. The Kainchi is a symbolic material that the tailor (Damai) uses to cut the clothes. In this context, the poem speaks the statement of revolt as "I know, today//If the scissors became inhuman like other// the wearing clothes may be cut// the human photos may be cut// the fingers may be cut// the hands may be cut// and..., // the national flag also may be cut" (trans. "Stanza V", 2073, p. 92). These revolutionary lines strongly portray the real anger against the discrimination. Calling the people to cut the national flag is not a trifle issue that a representative Dalit figure shows the anger against the system. It is a threat against the state's mechanisms and the so-called upper caste people who have for long suppressed Dalit community with religious and cultural backing. The selected representative poems are exemplary of protest literature against all types of discrimination in Nepali literary arena. These types of protest literature need to prescribe in higher education or universities so as to aware the upcoming generation; and to end all types of discrimination and oppression from the society. 


\section{Conclusion}

The subaltern problems are the universal issues of all times. Dalits as subalterns in South Asia is pertinent question to be solved. Dalit community is a product of Varna system; who has been living a life full of discrimination, exclusion, boycott and exploitation. Dalitsmostly dream for equality based rights and dignified lives. The Dalit movements and literary movements have also aimed to establish the society where they can enjoy the lives. The poetry as a part of protest writings show the socio-political problems, discrimination, exploitation and exclusion of Dalit community; and also make the stakeholders conscious about the rights, equality, dignity and social liberation; and motivate the stakeholders to work for establishing an equality-based prosperity society.

The poetry/poems by Aahuti and Harisharan Pariyar written on Dalit issues and subjects are really heart-touching and revolutionary to move the Dalits for rights movements which have realistically portrayed the true situation of Dalits in Nepal. The poems not only speak the pain and problems of Dalits but also speak the language of revolt and revolution against the system. The poems not only targeted to the social systems but also to the state mechanisms and discriminatory laws and practices. Both of Dalit poets strongly present the issues for Dalit rights, equality, dignity and social liberation in the poems. They encourage, motivate and energize the Dalits to raise the voice against the entire system and develop the equity based just society.

These poetic writings are strongly convincing to Dalits and concerned communities. These poems are good examplesof protest literature and voices from the margin. They question the socio-political position, historiography, roles in society; and raise the issues of contribution and efforts made by Dalit community in national building process. They both express their pain and anger, revolution and unified action against the discriminatory system and social malpractices. These poems are able to communicate about the overall situation of Dalits and future actions for equality, rights, dignity and social liberation of Dalits. But, the state and its mechanism have not yet realized that the social malpractices are the outcomes of our educational system. The schools and universities have not included the protest literature and writings in their curriculum to end the social evils and malpractices. Until and unless the state does not see the need of prescribing Dalit protest literature in university level to aware the wider communities and stakeholder for ending all types of discrimination from the society; the social malpractices cannot be removed easily. Hence, the article critically studied the poems written on Dalit issues and subjects from the subaltern perspective and able to move the Dalits and other concerned people to work against this form of 
discrimination. The researcher strongly urges stakeholders to prescribe the protest literature to end all types of discrimination through education and academic practices.

\section{Works Cited}

Aahuti. (2014) "Brown Africa". Varna System and Class Struggle in Nepal. Ed. Mahesh Raj Maharjan. Lalitpur: Samata Foundation, pp. 9- 11

---. (2071 BS) "Mero Kabitako Katha". Gahungoro Africa. Kathmandu: Sangrilla Books, pp. 89- 140

Bahl, Vinay. (1997) "Relevence (or Irrelevance) of Subaltern Studies". Economic and Political Weekly. Vol. 32. 23 (Jun. 7-13, pp. 1333- 1344). JSTOR. http://www.jstor.org/stable/4405482

Bala, Anju. (2014). "Giving Voice to Voiceless: A Study of Dalit Literature". Galaxy: International Multidisciplinary Research Journal. Vol. 3, Issue- II (March, pp. 36- 41)

Binabee, Kewal at. al. (Eds.). (2073 BS) "YaskaranUnmuktaAandolan". Aafar. Lalitpur: Samata foundation, pp. 95-99

---. (2073)."Shoodra Shambuk". Aafar. Eds. KewalBinabee at. al. Lalitpur: Samata Foundation, pp. 11- 13

Brueck, Laura R. (2014). Writing Resistance: The Rhetorical Imagination of Hindi Dalit Literature. New York: Columbia University Press

Chapagain, Ninu. (2070 BS) "Dalit Soundaryashashtra ra Sahitya". Dalit Soundarya Bodh. Ed. Rajendra Maharjan. Lalitpur: Samata Foundation, pp. 55- 110

Guha, Ranajit. Ed. (1982). Subaltern Studies I. Delhi: OUP

Hornby, A. S. (2000). Oxford Advanced Learner's Dictionary of Current English (Sixth Edition). Ed. Sally Wehmeier. New York: Oxford University Press

Hunt, Sarah Beth. (2014). Hindi Dalit Literature and the Politics of Representation. New Delhi: Routledge

Limbale, Sharankumar. (2004). Towards an Aesthetic of Dalit Literature: History, Controversies and Considerations. trans. Alok Mukherjee. New Delhi: Orient Longman Pvt. Ltd

Nagar, Ranjana. (2017). "Defining Dalit Aesthetics". The Criterion: An International Journal in English. Vol. 8. III (June, pp. 126- 133) https://www.the-criterion.com/V8/n3/IN17.pdf

Nepali BrihatShabdakosh. (2067 BS). Nepal Pragya-Pratishthan, Kathmandu

Pariyar, Harisharani. (2073 BS). "Kainchi". Aafar. Eds. KewalBinabee at. al. Lalitpur: Samata Foundation, pp. 91- 92

---. "Pasinako Hisab". Aafar. Eds. (2073 BS). KewalBinabee at. al. Lalitpur: Samata Foundation, pp. 87- 88

---. "Sanai". Aafar. Eds. (2073 BS). KewalBinabee at. al. Lalitpur: Samata Foundation, pp. 85- 86

Savyasaachi. (2004). "Dalit Studies: Exploring Criteria for a New Discipline". Economic and Political Weekly. Vol. 39, No. 17 (Apr. 24-30, pp.1658- 1660), JSTOR. http://www.jstor.org/stable/4414922

Spivak, Gayatri Chakravorty. (1988). "Can Subaltern Speak?”. Marxism and the Interpretation of Culture. Cary Nelson and Lawrence Grossberg (eds.). London: Macmillan, pp. 24-28

Sunar, Pabitra. (2073 BS). YugakoAawaj. Kathmandu

Sundas, Padam. (2070 BS). "Dalit Sahityako Nalekhiyeko Itihas". Dalit Soundarya Bodh. Ed. Rajendra Maharjan. Lalitpur: Samata Foundation, pp. 33- 54

Wordsworth, William. (1805). "Preface". Lyrical Ballads. The Harvard Classics (Fourth Edition), pp. 1- 14 